\title{
Expression of Metallothionein in Oral Cancer
}

\author{
Dziegiel Piotr, Pula Bartosz and Podhorska-Okolow Marzena \\ Department of Histology and Embryology, Wroclaw Medical University \\ Poland
}

\section{Introduction}

Metallothioneins (MTs) are ubiquitous proteins expressed in almost all organisms. MTs were isolated in 1957 for the first time from renal cortex as proteins responsible for binding cadmium (Margoshes \& Valee, 1957, Coyle et al., 2002, Vasák et al., 2005). MTs are highly evolutionary conserved between species. Nevertheless, the role of these proteins has not been fully clarified yet and continues to generate interest among researchers. At present, several studies on MTs are focused on, their significance in the process of carcinogenesis, their potential prognostic value, and their involvement in resistance to cytostatic drugs.

\subsection{MT structure and synthesis}

MTs are low molecular weight of 6-7 kDa proteins. The molecules of MT demonstrate a highly conserved amino acid sequence: the protein isolated from various organs of various animal species differ only insignificantly (Vasák et al., 2000). The molecule is formed by a single polypeptide chain of 61 to 68 amino acids, depending on the type. About $30 \%$ of MTs comprise of cystein residues while aromatic amino acids and histidine are absent. The cystein residues occur in typical tandem sequences of cys-aa1-cys, cys-aa1-aa2-cys, cys-cys, where aa1 and aa2 denotes amino acid other than cystein. The number and distribution of the sequences determine the tertiary structure, stability, and capability for binding metallic ions. The high number of cystein residues is a source of high content of thiol groups (-SH) through which metal ions are bound (Coyle et al., 2002). Their ability to bind heavy metals, such as zinc, copper, mercury, lead, nickel, iron and cadmium has been demonstrated in many studies. One MT molecule may bind up to seven ions of bivalent, and up to twelve ions of univalent metals (Palmiter et al., 1998). In the structure of MT two globular domains can be distinguished, a and $\beta$ (Zangger et al., 2002). The C-terminal domain a comprises amino acids $31-68$ and binds four $\mathrm{Cd}$ ions while the N-terminal domain $\beta$, comprises amino acids 1 to 30 and captures three metal ions, including two Zn ions and one $\mathrm{Cd}$ ion. Within the MT molecule, the most pronounced antigenicity is shown by regions of the domain $\beta$ (Dziegiel, 2004). MTs represent a non-uniform group of proteins. Analysis of their structure and function allowed distinction into four principal isoforms: MT-1, MT-2, MT-3 and MT-4 (Mididoddi et al., 1996). Isoforms MT-1 and MT-2 are well recognized and characterized because they are expressed almost in all tissues of the organism. The highest concentrations of these proteins were demonstrated in the kidney, liver, pancreas and intestine (Davis et al., 2000; Coyle et al., 2002). Expression of MT-3 and MT- 4 isoforms is tissue specific and are present in the body in much lower amounts. MT-3 can be noted mainly in cerebral neurons of central nervous system (Hidalgo et al., 2001). The 
expression of MT-4 is restricted to stratified squamous epithelium of the skin and upper part of the alimentary tract (Quaife et al., 1994). MT are encoded by 17 genes, including 13 genes that code for MT-1, two for MT-2, and individual genes coding for MT-3 and MT-4. There are at least 10 MT genes which encode functional proteins: MT-1A, MT-1B, MT-1E, MT-1F, MT1G, MT-1H, MT-1X, MT-2A, MT-3 and MT-4 (Palmiter et al., 1992; Quaife et al., 1994). In human, genes encoding for MTs are located on chromosome 16, within the 16q13 region (Mididoddi et al., 1996). MTs are intracellular proteins and their presence was demonstrated in the cytoplasm and in the cell nucleus (Bay et al., 2001). Their synthesis can be induced by several substances, such as heavy metals, hormones, cytokines, growth factors, organic compounds and free radicals (Samson et al., 1998; Haq et al., 2003; Ghoshal et al., 2001). The principal physiological factors, which induce MT synthesis are zinc ions $\left(\mathrm{Zn}^{2+}\right)$ which are bound by the transcription factor, MTF-1 (metal response element-binding transcription factor). The MTF-1 is a protein with domains of zinc finger structure, responsible for interaction with DNA. The MTF-1 binds to the MRE (metal response element) sequence within the MT gene promoter. Binding of MTF-1 to MRE initiates the process of MT gene transcription (Langmade et al., 2000; Otsuka et al., 2000; Saydam et al., 2002). The remaining metals (e.g. $\mathrm{Pb}^{2+}, \mathrm{Ni}^{2+}, \mathrm{Fe}^{2+}$, $\mathrm{Cd}^{2+}, \mathrm{Bi}^{2+}$ ) initiate transcription of MT genes also with mediation of MRE but they are not bound by the MTF-1 transcription factor. They manifest a higher affinity to MT and they replace zinc ions from MT molecules. Released zinc ions are subsequently bound by MTF-1 (Mursta et al., 1999; Koizumi et al., 1999; Lichtlen et al., 2001). Similarly, oxygen free radicals could also replace zinc ions from MT molecule and in this way stimulate MT synthesis. Oxidation of MT by hydrogen peroxide $\left(\mathrm{H}_{2} \mathrm{O}_{2}\right)$ leads to release of zinc ions (Andrews, 2000; Nguyen et al., 2003). MT synthesis could also be induced by other factors, such as glucocorticoids, which through glucocorticoid receptors (GR) bind to specific regulatory sequences, GRE (glucocorticoid response element) in the promoter region of MT genes (Davis et al., 2000; Hernández et al., 2000).

\subsection{Effect of MT on cell proliferation and differentiation processes}

MTs are thought to be engaged in the control of cell proliferation and differentiation (Schmidt et al., 1999). The metal binding properties of MT, including binding of zinc ions, allow MT to act as a zinc donor. The zinc-dependent enzymes play a crucial role in DNA replication, transcription and protein biosynthesis. Presumably, in this way MT could modulate the functional activity of many factors controlling the cell cycle (Ostrakhovitch et al. 2007). In the course of cell cycle the distribution of MT in the cell is changed from the cytoplasm to the nucleus, what may indicate the protein's involvement in DNA synthesis. In many studies an increased expression of MT both in the cell nucleus and in the cytoplasm was demonstrated in hepatocytes during liver regeneration, in kidneys undergoing compensatory growth following nephrectomy, and in rapidly growing parabasal cells of stratified squamous epithelium (Zalups et al., 1995; Ioachim et al., 1999; Cherian et al., 2006). The increased expression of MT, correlated to the augmented cell proliferation, was also observed in cells of various human tumours (Theocharis et al., 2004). In mitotically inactive cells (G0 phase) expression of MT can be detected in the cytoplasm while in dividing cells its activity becomes shifted to the nucleus. The high cytoplasmic expression of MT is observed at the end of G1 phase and at the G1/S threshold while the peak accumulation of MT in cell nucleus can be detected in phases S and G2 (Cherian et al., 2000; Levadoux-Martin et al., 2001). The translocation of MT into the nucleus during G1/S phase in tumour cells suggests 
that MT facilitates cell proliferation by donating zinc ions to various transcription factors. The stabilization and binding of transcription factors to DNA depend entirely on zinc binding (Ostrakhovitch et al. 2007). In this way MT may control activity of various genes, including the p53 tumour suppressor protein in cells. In in vitro studies the transfer of zinc ions from MT to transcription factors was demonstrated (Langmade et al., 2000). The factors involve mainly protein factors with zinc fingers domains in their structures, such as estrogen receptors and MTF-1. Binding of zinc ions by MT was found to be a reversible process: in certain conditions MT may remove zinc from other protein molecules, in this way modulating their biological activity (Davis et al., 2000; Ogra et al., 2001).

\subsection{Role of MT in a neoplastic process}

Recent investigations confirmed that increased synthesis of MT occurs in neoplastic cells of various origin (Dziegiel, 2004). Investigators have focused on the significance of MT in the process of carcinogenesis and tumour progression but also on the involvement of the proteins in development of tumour chemoresistance as well as the possible role of MT expression as a prognostic and predictive factor. Results of several investigations suggest that the role of MT expression in tumour cells may be linked to the processes of proliferation and apoptosis (Jayasurya et al., 2000; Bay et al., 2001; Shimoda et al., 2003). MT functions as a donor of zinc ions for transcription factors and enzymes involved in the processes of DNA and protein synthesis. This is confirmed not only by elevated MT levels in hyperplasia but also by MT translocation from cytoplasm to cell nucleus during DNA synthesis (S phase) (Woo et al., 1996; Jasani \& Schmid, 1997). In neoplastic tissues, the level of MT was shown to be proportionally elevated with the concentration of zinc ions (Jayasurya et al., 2000; Florianczyk et al., 2006). Similar results have been shown in in vitro investigations, showing that interaction between MT and p53 protein seems to be highly significant for tumour development, due to regulation of zinc ion homeostasis by MT (Meplan et al., 2000; Ostrakhovitch et al., 2006). p53 protein represents a transcription factor with a DNA-binding domain, stabilized by zinc ions. In normal conditions it inhibits proliferation of cells with a damaged DNA and directs cells toward apoptosis. MT molecules were found to be able to remove zinc ions from p53 protein, what results in its inactivity (Rainwater et al., 1995; Meplan et al., 2000). Inactivation of p53 protein in neoplastic cells results in their excessive proliferation and in inhibition of apoptotic processes. It is suggested that an increased synthesis of MT in tumour cells promotes interaction of MT with p53 protein, resulting in an uncontrolled proliferation (Fan et al., 2002; Ostrakhovitch et al., 2007). The results were confirmed by positive correlation between expression of MT and proliferation antigens, Ki-67 and PCNA. Such a relationship was demonstrated in several tumours, such as breast cancer, cancers of ovary, kidney, and also in tumours of lungs and upper respiratory pathways (Jayasurya et al., 2000; Jin et al., 2001; Hengstler et al., 2001; Harpole et al., 2001; Mitropoulos et al., 2005). Therefore, expression of MT may be of prognostic significance in certain types of tumours. Several reports investigated the relationship between MT expression and other clinicopathological characteristics of various malignancies. In certain tumours, e.g. in colorectal carcinoma overexpression of MT was found more often in cases of tumours of a higher grade of malignancy (Dziegiel et al., 2003). An elevated level of MT was found to correlate with an abbreviated duration of survival and a shorter disease free survival in some tumour types, what may suggest usefulness of MT as a prognostic factor (Dziegiel, 2004). However, some reports did not confirm the prognostic role of MT expression, what does not permit at present to unequivocally specify prognostic value of MT in neoplastic diseases. MT was also shown to be involved in the development of 
resistance of cancer cells to cytostatic agents. Chemotherapy was found to induce synthesis of MT while an elevated level of the proteins decreased therapeutic efficacy of certain oncostatic proteins (Cherian et al., 2003). In several investigations it was demonstrated using experimental animals with engrafted tumour cells treated with drugs commonly used in antineoplastic therapy, including cisplatin, bleomycin, cyclophosphamide, that synthesis of MT in neoplastic cells increased markedly. In parallel, other drugs, such as mitomycin C, 5fluorouracil did not alter MT expression level. Animals with engrafted tumour cells with zincinduced MT, were shown to have significantly higher rate of chemoresitance of tumour cells to cisplatin as compared to the untreated cells. The experiments showed that MT may be responsible for both primary and acquired chemoresistance of neoplastic cells (Florianczyk, 1999; Chun et al., 2004). Mechanism of the cytoprotective MT activity during chemotherapy seems to be related to an anti-oxidative properties of MT. Some anti-neoplastic drugs act by inducing oxidative stress in tumour cells (including anthracyclines, e.g.. doxorubicin, daunorubicin), what results in their damage. MT protect cells from oxidative damage, decreasing therefore the therapeutic efficacy of cytostatic drugs (Cherian et al., 2003). In turn, affinity of MT to metal ions provides grounds for inactivation of alkylating drugs containing heavy metals (e.g. cisplatin, carboplatin). Due to MT direct interaction with the chemotherapeutic agents or their metabolites, MT may protect neoplastic cells from the cytotoxic effects (Shimoda et al., 2003; Theocharis et al., 2004). This hypothesis is confirmed by studies conducted on human malignancies (e.g. ovarian cancer, testicular cancer, colorectal cancer, breast cancer and squamocellular oesophageal cancer), showed that insensitivity of the tumours to chemotherapy was related to their MT over-expression (Yamamoto et al., 1999; Vazquez-Ramirez et al., 2000; Dziegiel et al., 2003; Surowiak et al., 2005; Surowiak et al., 2007). In view of the above, some authors include MT, in parallel to multi-drug resistance proteins $(M D R)$, to significant factors responsible for the lack of therapeutic efficacy of some cytostatic agents (Theocharis et al., 2004). Similar observations were shown regarding resistance of tumour cells to radiotherapy, which is known to generate high amounts of free radicals in tumour cells. MT, playing the function of an intracellular antioxidant inactivate reactive oxygen species, therefore protecting the tumour cells from radiotherapy induced damage, resulting in treatment failure (Cai et al., 1999; Theocharis et al., 2004). Although the role of MT in the process of carcinogenesis, proliferation and resistance of tumour cells to chemo- and radiotherapy still requires further research, MT may be considered as an additional prognostic and predictive marker in some tumour types.

\section{Metallothionein in oral cancer}

As overexpression of MT-1 and MT-2 was found in many malignant tumours, the studies conducted on cancers of the oral cavity concerning MT expression focused mainly on the expression of these two isoforms in oral squamous cell carcinoma (OSCC), tonque squamous cell carcinoma and tumours of the salivary glands.

\subsection{Metallothionein expression in normal and dysplastic oral mucosa and oral squamous cell carcinoma}

OSCC is the most frequently diagnosed oral cancer accounting for more than $95 \%$ of malignancies originating from the oral cavity with almost 25000 new cases diagnosed annually in the US (Siegel et al., 2011). Oral leukoplakia (OL) is a premalignant and potentially malignanant lesion of the oral mucosa and proceeds OSCC in some cases (Hunt et al. 2011). On 
the basis of the amount of dysplastic cells and the thickness of dysplastic epithelium, this lesion is graded as mild, moderate or severe (Barnes et al., 2005). Until now, in tissues of the oral mucosa and its lesions, only isoforms of the MT-1 and MT-2 family were investigated concerning their expression. In normal oral mucosa MT-1/2 expression is restricted only to basal and parabasal cells with a mosaic cytoplasmic-nuclear expression pattern, whereas in dysplastic lesions additional foci in the spinous layer were noted (Sundelin et al., 1997; Johann et al., 2008; Pontes et al., 2009). MT-1/2 expression intensity was positively correlated with severity of dysplasia of oral leukoplakia, with the lowest MT-1/2 expression found in mild dysplastic lesions and the highest in severe dysplasia (Pontes et al., 2009). Likewise in normal and dysplastic mucosa, cancer cells of OSCC exhibited an cytoplasmic-nuclear pattern of MT1/2 expression (Szelachowska et al., 2008; Pontes et al., 2009). In OSCC, cancer cells expressing MT-1/2 were found at the centre and the periphery of tumour islands, but interestingly in cases when keratin pearls were present, MT-1/2 expression was restricted to basal and parabasal cells (Pontes et al., 2009, Szelachowska et al, 2009).

\subsubsection{Role of metallothioneins in the pathogenesis of oral squamous cell carcinoma}

Three major risk factors of OSCC development are long term tobacco smoking, alcohol and areca-quid (also known as betel nut) consumption (Shiu et al, 2004). Two components of tobacco: nicotine and 4-(methylnitorosamino)-1-(3-pyridyl)-1-butanone were shown to activate Akt kinase in human airway epithelial cells (West et al., 2003; Shiu et al., 2004; West et al., 2004). Recent studies reported, that MT-1/2 expression correlated positively with phosphorylated Akt (p-Akt) expression and levels of both these proteins were significantly elevated in OSCC in comparison to normal or dysplastic oral mucosa regardless of its severity grade (Sundelin et al., 1997; Johann et al., 2008; Pontes et al., 2009). Akt/PKB (protein kinase $\mathrm{B}$ ) is a serine/threonine kinase comprised of three isoforms and acts as a downstream target of phosphatidylinositol-3 kinase (PI3K) and is thus involved in many vital cellular pathways and is frequently activated in different human cancers (Carnero 2010; Fayard et al, 2010; Freudlsperger et al., 2011; Grabinski et al., 2011;). Its activation, similarly to MT-1/2 expression, in human cancers was associated with inhibition of apoptosis and promotion of cell proliferation (Diehl et al., 1998; Brunet et al., 1999). Epidemiological studies have also shown, that patients with head and neck cancer and OSCC frequently suffer from zinc deficiency (Doerr et al., 1997; Kleier et al., 1998). These results were also confirmed by a number of in vivo studies using an lingual-esophageal carcinogenesis model in mouse and rats (Fong et al., 2005; Fong et al., 2006, Liu et al., 2005). These studies have shown that deficit of zinc in diet induces MT-1 expression, along with other markers related to carcinogenesis e.g. cyclin-B2, carbonic anhydrase II and keratin 14. Moreover, zinc diet restriction potentiated the growth of lingual and esophageal tumours in p53 deficient mice, which were characterized by significantly augmented cell proliferation, keratin 14, COX-2 and MT-1 expression as compared to mice with normal p53 expression level (Liu et al., 2005; Fong et al., 2006). Zinc replenishment in the diet resulted in subsequent reduction of cell proliferation and expression of keratin 14, COX-2 and MT-I (Liu et al., 2005). These experimental results confirm the observations stemming from IHC studies on human specimens, because the carcinogenesis model clearly showed subsequent rise of MT-1 expression correlating with the noted histopathological hyperplasia-dysplasiacarcinoma model (Fong et al., 2006). Nonetheless, little is known about the interaction and possible regulation of MT-1 and MT-2 expression in dysplasia and OSCC cases. 

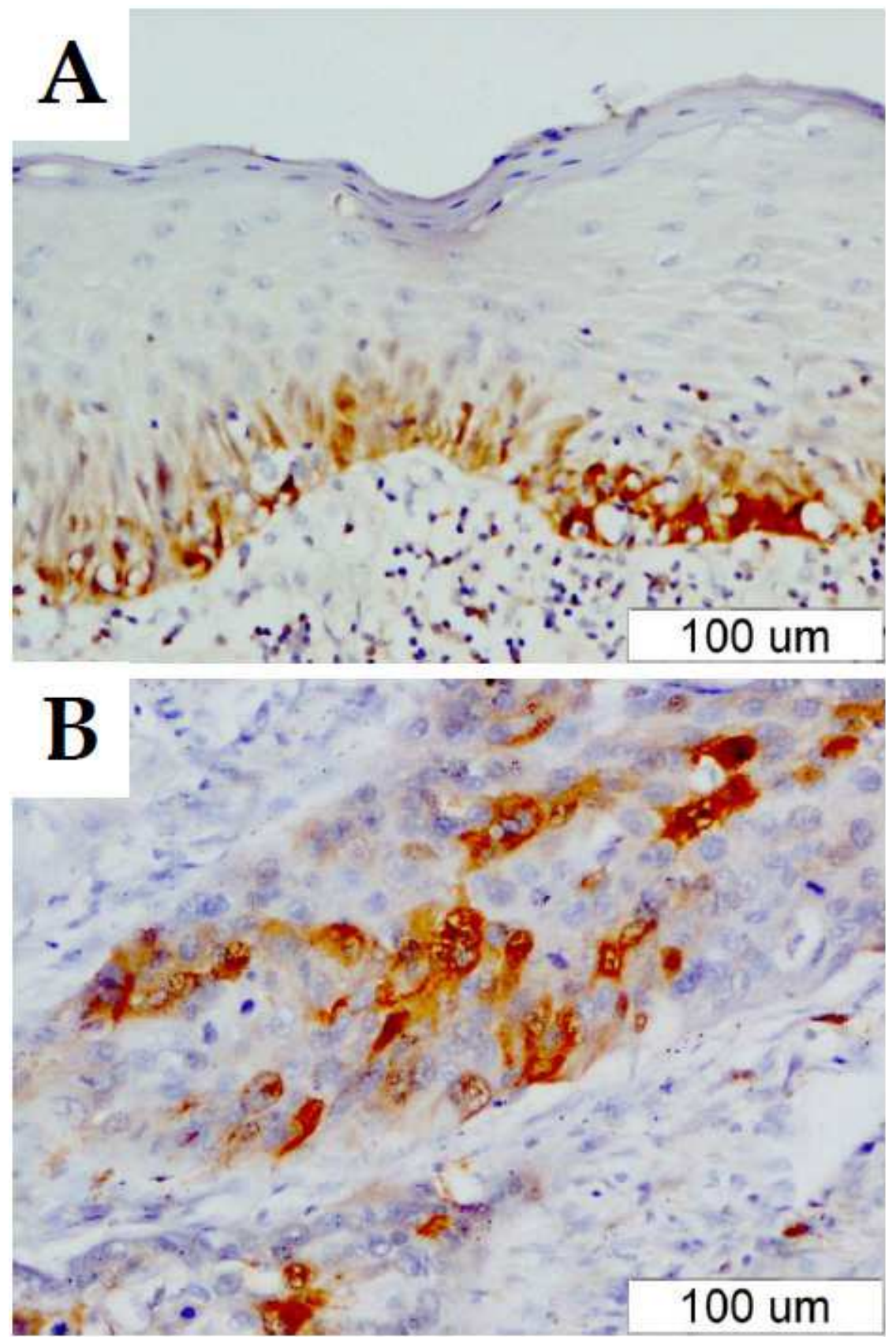

Fig. 1. MT-1/2 expression in basal layer of squamous stratified epithelium with additional foci in the upper parts of oral mucosa (A). Nuclear-cytoplasmic MT-1/2 expression in advanced OSCC (B). 


\subsubsection{Areca nuts, copper ions and reactive oxygen species (ROS)}

Areca nuts chewing was shown to be associated with increased risk of OSCC development and progression (Shiu et al., 2004; Merchant et al., 2000). It is estimated that around 200-400 million people, regardless of gender consume areca nuts (Gupta and Warnakulasuriya, 2002). Moreover, almost $80 \%$ of OSCC related deaths in Taiwan are associated with areca quid consumption habit (Kwan, 1976; Lee et al., 2008). It was shown, that patients with simultaneous smoking and areca nut chewing habits are characterized be even greater risk of OSCC development, than patients consuming either of these products separately (Ko et al., 1995). The study of Lee et al. showed an upregulated expression of MT-1 in OSCC originating from patients with long-term areca nut consumption (Lee et al., 2008). Areca nuts contain high levels of copper, a metal which is bound by metallotthioneins, and is the source of ROS during chewing (Trivedy et al., 1997; Nair et al., 1992; Chen et al., 2002). This compounds were shown to be responsible for generation of OSCC in areca quid consumers (Warnakulasuriya et al., 2002). The in vitro experiments conducted on an oral epithelial cell line GNM originating from a patient with T2N2aM0 gingival carcinoma demonstrated an increase in MT-1 mRNA expression upon arecoline treatment in a dose dependent manner (Lee et al., 2008). Treatment of this carcinoma cell line with benzo[a]pyren (BaP) alone or in combination with arecoline resulted in an increased expression of MT-1 mRNA in GNM cells. The highest MT-1 mRNA expression was seen in the cells treated with both compounds simultaneously. Addition of a glutathione precursor, $\mathrm{N}$-acetyl-L-cyteine, to the cells treated with arecoline reduced the levels of arecoline induced MT- 1 mRNA levels. Nonetheless, the results of the in vitro experiments are in accordance with the results of the epidemiological studies conducted on Taiwan population, showing an enhanced incidence of OSCC development in patients with simultaneous areca quid and cigarette consumption (Ko et al., 1995, Lin et al., 2011). Moreover, this results also underlie the results of studies showing upregulated expression in response to reactive oxygen species (Iqbal et al., 2003; Reinecke et al., 2006). As areca nuts contain also high amounts of copper ions, high MT-1/2 expression in OSCC originating from areca nut chewers may be partially explained by its interaction with this metal ion. To note, studies have shown, that MT-1/2 expression levels is related to zinc and copper ion content in tumour cells, what points to another mechanism of MT-1/2 upregulated expression in OSCC cells originating from areca-quid consumers (Jayasurya et al., 2000; Florianczyk et al., 2006).

\subsubsection{Cancer cell proliferation}

Few studies compared the proliferative activity of OSCC tumour cells with expression levels of MT-1/2 (Cardoso et al., 2002; Szelachowska et al., 2008; Szelachowska et al., 2009). None of the studies performed on OSCC cases succeeded in noting a positive correlation between MT-1/2 expression and expression of proliferation markers. The study of Cardoso et al. found no correlation between the expression of MT-1/2 and Ki-67 antigen (Cardoso et al., 2002). Similar results were obtained in both studies performed by Szelachowska et al. on a subset of patients with OSCC (Szelachowska et al. 2008; Szelachowska et al., 2009). In the first study no correlation with Ki-67 and MCM-2 protein expression was found, when the MT-1/2 nuclear and cytoplasmic expression was analyzed separately (Szelachowska et al. 2008). Similarly, no correlations were found in the second study performed on 39 patients with OSCC between MT-1/2 expression intensity and cancer cell proliferation measured by the Ki-67 and MCM-2 expression levels (Szelachowska et al., 2009). MT-1/2 expression 
seems not to exert pro-mitotic effects in OSCC, which was observed in other tumour types, including the squamous cell carcinoma of the head and neck (Jayasurya et al., 2000; Dziegiel et al., 2005; Szajereka et al., 2008).

\subsubsection{3 p53}

Recent study performed on 100 cases of OSCC disclosed a positive correlation between the expression of MT-1/2 and p53 protein. Moreover, cases characterized by a positive nuclear MT-1/2 immunostaining yielded higher p53 expression levels (Cardoso et al., 2009). This underlies the earlier observed role of MT-1/2 in regulation of p53 expression by influencing zinc ion cell homeostasis (Rainwater et al., 1995; Meplan et al., 2000; Ostrakhovitch et al., 2006; Pastuszewski et al., 2007).

\subsubsection{Invasiveness}

Numerous studies showed the involvement of laminin in progression of different malignancies, including these of the oral cavity (Ono et al., 1999; Patarroyo et al., 2002; Stolzfus et al., 2004; Lyons and Jones, 2007). Until now, only one study analyzed the impact of MT-1/2 expression levels on the expression of invasiveness related markers in OSCC. In this immunohistochemical study a positive correlation was disclosed between the expression of MT-1/2 and laminin-5 (Szelachowska et al., 2009). Lamin in normal conditions is expressed in the epithelial basement membrane and its expression increases with severity of the dysplasia and may regulate cell motility (Kainulainen et al., 1997; Décline \& Roussel, 2001; Décline et al., 2003, Lyons and Jones, 2007). This might explain the higher expression of MT-1/2 in tumours with the presence of lymph node metastases in comparison to tumours without lymph node involvement (Szelachowska et al., 2009).

\subsubsection{Chemoresistance}

As metallothionein isoforms were suggested to play a role in cancer cells chemoresistance, Nakano et al. studied the impact of cisplatin treatment of human tongue squamous cell carcinomas on MT expression (Nakano et al., 2003). These cells expressed the MT-1, MT-2 and MT-4 isoforms, whereas no expression of MT-3 was noted. The subsequent treatment of the cells with cisplatin resulted in a significant increase of expression of only the MT-1 and MT-2 isoforms in cisplatin-resistant cells (Nakano et al., 2003). Role of MT-1/2 in OSCC chemoresistance was also issued in the work of Muramutsu et al., but no difference in MT-1/2 expression levels between the treated and untreated patients was noted (Muramutsu et al., 2000).

\subsubsection{Clinical implications of MT expression in OSCC}

Until now six studies (Table 1) investigated the impact of MT expression regarding patients clinicopathological characteristics (Muramatsu et al., 2000; Cardoso et al., 2002; Lee et al., 2008; Szelachowska et al., 2008; Cardoso et al., 2009; Szelachowska et al., 2009). All those studies were performed on archival paraffin blocks from patients whose cancers originated mainly from oral mucosa, but in some cases specimens from cancers of the mobile part of the tongue were included (Szelachowska et al., 2008; Szelachowska et al., 2009). In case of only one study three additional tumours from the maxilla region were investigated (Muramutsu et al., 2000). Except one study of Lee et al., a primary antibody directed against MT-1/2 isoforms was used. None of the mentioned studies showed correlations with 
primary tumour size, grade of tumour differentiation and proliferation markers (Ki-67 and MCM-2). In three studies, a positive correlation was noted between lymph node involvement and the intensity of MT expression (Lee et al., 2008; Szelachowska et al., 2008; Szelachowska et al., 2009). Studies which analyzed the impact of metallothionein expression on patients outcome, showed that elevated MT-1/2 expression in patients with OSCC was generally an unfavourable prognostic marker (Cardoso et al., 2002; Szelachowska et al., 2008; Cardoso et al., 2009). In the study of Cardoso et. al., MT-1/2 cell positivity (cytoplasmic-nuclear staining) was counted and enrolled in the survival analysis. Univariate analysis, as well as multivariate analysis showed that MT-1/2 overexpression was an unfavorable prognostic factor in the studied patient cohort (Cardoso et al., 2002).

\begin{tabular}{|c|c|c|c|c|c|c|}
\hline Publication & 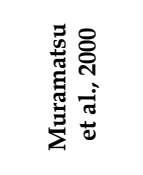 & 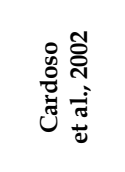 & 芯 & 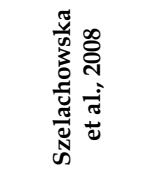 & 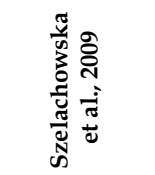 & 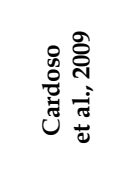 \\
\hline Patients & $\begin{array}{c}28 \text { OSCC } \\
\text { and NPC; } 3 \\
\text { cancers of } \\
\text { the maxilla } \\
\text { region }\end{array}$ & 60 OsCC & $* 34$ OSCC & 50 OSCC & 39 OsCC & $100 \mathrm{OSCC}$ \\
\hline MT isoform & MT-1/2 & MT-1/2 & MT-1 & MT-1/2 & MT-1/2 & MT-1/2 \\
\hline pT & - & - & - & - & - & NA \\
\hline pN & - & - & + & + cytoplasm & + & NA \\
\hline $\begin{array}{l}\text { Grade of malignancy } \\
\text { (differentiation) }\end{array}$ & NA & - & - & - & - & - \\
\hline Clinical stage & NA & - & - & not analyzed & $\begin{array}{c}\text { not } \\
\text { analyzed }\end{array}$ & - \\
\hline Survival & NA & $\begin{array}{c}\text { poor } \\
\text { prognosis }\end{array}$ & NA & $\begin{array}{c}{ }^{*} \text { poor } \\
\text { prognosis }\end{array}$ & $\begin{array}{c}\text { not } \\
\text { analyzed }\end{array}$ & $\begin{array}{c}{ }^{*} \text { poor } \\
\text { prognosis }\end{array}$ \\
\hline Proliferation & (-) Ki-67 & (-) Ki-67 & NA & $\begin{array}{l}\text { (-) Ki-67, } \\
\text { (-) MCM-2 }\end{array}$ & $\begin{array}{c}\text { (-) Ki-67, } \\
\text { (-) MCM-2 }\end{array}$ & - \\
\hline Other markers & NA & NA & NA & NA & $\begin{array}{l}\text { (+) Laminin- } \\
5\end{array}$ & $(+)$ p53 \\
\hline Notes & & & $\begin{array}{l}{ }^{*} \text { Areca quid } \\
\text { consumers }\end{array}$ & $\begin{array}{l}{ }^{*} \text { shorter DFS } \\
\text { and DSS in } \\
\text { patients } \\
\text { with high } \\
\text { MT-1/2 } \\
\text { expression; } \\
\text { lack of } \\
\text { significant } \\
\text { impact on } \\
\text { SFLR and } \\
\text { OS }\end{array}$ & & $\begin{array}{c}{ }^{*} \text { combined } \\
\text { high } \\
\text { expression } \\
\text { of MT- }-1 / 2 \\
\text { and p53 on } \\
\text { OS }\end{array}$ \\
\hline
\end{tabular}

Abbreviations: SFLR - survival free of locoregional relapse; DFS - disease free survival; OS - overall survival; DSS - disease specific survival; NA - not analyzed

Table 1. Summary of studies on MT expression with regard to patients clinicpathological characteristics. (-) represents lack of correlation or relationship between the analyzed variables, whereas $(+)$ represents positive correlations. 
A more detailed analysis of MT-1/2 expression on patients outcome was performed in the study of Szelachowska et al., where cytoplasmatic and nuclear MT-1/2 expressions were analyzed separately (Szelachowska et al., 2008). For the nuclear evaluation, cells showing positive reaction were counted, whereas, for the evaluation of cytoplasmatic reaction an immunoreactive score (IRS) of Remmele and Stegner based on evaluation of number of positive cells and the intensity of colour reaction took advantage (Remmele \& Stegner, 1986). The authors noted a significant correlation between the cytoplasmatic and nuclear MT-1/2 expression, but none of the evaluated types of the reaction correlated with tumour size, grade of malignancy or expression of both proliferation markers (Ki-67 and MCM-2). Interestingly, only in cases with lymph node involvement, a significant increase in MT-1/2 expression was noted when compared to cases without lymph node involvement (Szelachowska et al. 2008). Also differences regarding patients survival differed among the both analyzed expression patterns. The univariate analysis showed that cases characterized by high cytoplasmatic MT-1/2 expression had a significantly shorter disease specific survival (DSS) and disease free survival (DFS), whereas cases with high nuclear MT-1/2 expression had a significantly shorter DFS and tended to have also a shorter DSS, but this trend did not reach statistical significance. No impact of MT-1/2 expression in the cytoplasm or nucleus affected significantly patients overall survival (Szelachowska et al., 2008). In another study of Cardoso et al., no influence on patients survival was observed, when MT-1/2 expression was analyzed alone. Interestingly, a combined analysis of this protein with p53 expression, showed that high expression of both these markers predicted poor outcome of patients with OSCC (Cardoso et al, 2009). Differences in the studies concerning lymph node involvement and patients survival, may by caused be heterogenous origin of specimens used in the study (Szelachowska et al., 2008; Szelachowska et al., 2009) In summary, the above mentioned studies highlight and underlie the potential role of MT$1 / 2$ expression in the development and tumour progression of OSCC.

\subsection{Metallothionein expression in normal salivary gland and its lesions}

MT were shown to be expressed in normal salivary glands as well as in benign and malignant tumours mainly in cells resembling the phenotype of myoepithelial cells (Sunardhi-Widyaputra et al., 1995; Gao et al., 1997; Hecht et al., 2002; Ogawa, 2003; Alves et al., 2007). As in the case of OSCC, the majority of studies concerning the role of MT expression in salivary glands were based on immunohistochemistry (Sunardhi-Widyaputra et al., 1995; Gao et al., 1997; Ogawa, 2003; Alves et al., 2007).

\subsubsection{Role of MT in salivary gland development}

MT seem to be involved in salivary gland development as shown in the studies of Hecht et al. (Hecht et al., 2002). It was found that MT is mainly the only upregulated family of genes, when human salivary gland (HSG) cells, derived from a human submandibular tumour, were cultured on a laminin-1 gel in different conditions. In gel cultures lamin-1 stimulates HSG cells to form acinar-like structures within 24-48 hours, whereas in the absence of laminin-1 in culture conditions results in a monolayer growth type. Also in microgravity culture conditions laminin-1 affects HSG cells growth by facilitating acini formation (Hoffman et al., 1998). It was seen that under laminin-1 culture conditions mRNA expression of three members of the MT family was significantly upregulated: MT-1F, MT-1B and MT-2. Subsequent immunostaining of these cells revealed a higher cytoplasmic 
MT-1/2 expression in comparison to HSG cells cultured in the absence of laminin- 1 . An overexpression of MT-1F in HSG cells did not affect cell proliferation as compared to native and control mock-transfected cells, but MT-overexpressing cells were characterized by an augmented growth after addition of low concentrations of zinc and copper to the medium (Hecht et al., 2002). MT-overexpressing cells grew in aggregates, were larger and had more pronounced adhesive properties than the parental cells. Moreover, MT-overexpressing cells formed acini-like structures larger and faster. Despite the strong impact on cellular differentiation, MT-overexpression did not affect amylase expression or mucin production. Interestingly, when these cells were injected s.c. to nude mice, tumours formed by MToverexpressing HSG cells were significantly smaller and more differentiated than the tumours formed by the parental cells (Hecht et al., 2002). Although, no differences in cell proliferation were observed in vitro, tumours originating from MT-overexpressing cells seemed to have more mitotic cells in the tumour mass (Hecht et al., 2002).

\subsubsection{MT expression in normal salivary gland tissues and neoplasias}

Normal salivary glands and its tumours exert a broad expression of MT-1/2 in myoepithelial cells (Sunardhi-Widyaputra et al., 1995; Gao et al., 1997; Ogawa, 2003; Alves et al., 2007, Prasad et al., 2008). In the study of Sunardhi-Widyaputra et al., performed on 21 benign and 4 malignant lesions of salivary glands, MT expression was compared with parathyroid hormone-related peptide (PTHrP) expression. In benign changes (pleomorphic adenoma, Warthin's tumour), both these proteins were coexpresed. In myoepthelioma majority of the cells expressed MT, while few have shown PTHrP reactivity. In oncocytoma, peripheries of oncotytic islands showed MT expression, while only few oncotytic PTHrP positive cells were noted. In cases of mucoepidermoid carcinomas MT and PTHrP expression was the most heterogenous. MT positivity was seen in epithelial cells and PTHrP in cyst-like structures and squamous cells (SunardhiWidyaputra et al., 1995). Similar results regarding MT expression were noted by Gao et al. in myoepitheliomas and myoepithelial carcinomas (Gao et al., 1997). Although these studies did not quantified MT expression, they clearly showed that MT expression may vary in regard to tumour degree of differentiation with the most heterogenous expression in the most dedifferentieted and immature tumours (Sunardhi-Widyaputra et al., 1995; Gao et al., 1997). The results of these studies are also supported by the findings of Ogawa, which demonstrated MT expression in a subset of myoepithelial cells during salivary gland development (Ogawa, 2003). MT expression in myoepithelial cells of adenoid cystic carcinomas and polymporphous low-grade adenocarcinomas was also studied as a potential marker of differentiation of these two malignancies as they may pose problems in the pathological examination (Prasad et al., 2008). This study showed, that diffuse MT expression in combination with smooth muscle acitin, calponin and smooth muscle myosin heavy chain was strongly predictive for adenoid cystic carcinoma (Prasad et al., 2008). MT expression in adenoid cystic carcinomas varied according to histological subtype (Alves et al., 2008). The most pronounced MT-1/2 staining was seen in solid and cribiform as compared to tubular subtypes of this tumour. This results support the results stemming from studies conducted on other malignanancies, showing that elevated MT$1 / 2$ expression is linked to patients poor clinical outcome (Dziegiel, 2004). High expression of MT-1/2 in solid and low in tubular subtypes, may partially explain their distinct clinical outcome (Nascimento et al., 1986; Perez et al., 2006; Alves et al., 2008). 


\section{Conclusion}

MT expression in OSCC seems to be of importance for the development and progression of these cancer type. Although the results of the clinical studies were not concordant (due to small sample size, heterogenous patient cohort) it is worth to mention that some of them noted a relationship between high MT expression and cancer cell metastasis and associated MT overexpression with poor patients outcome. Despite the few reports concerning MT expression in salivary glands and its lesions, one might consider MT as an interesting point of future research, mainly due to the impact of MT-1F expression on salivary tumour cells differentiation and growth. Nonetheless, further studies are needed to better characterize the role of MT expression on OSCC and tumours of the salivary glands.

\section{Acknowledgment}

This work was supported by the scientific grant of Wroclaw Medical University, No. ST-442.

\section{References}

Alves SM, Cardoso SV, de Fátima Bernardes V, Machado VC, Mesquita RA, Vieira do Carmo MA \& Ferreira Aguiar MC. (2007). Metallothionein immunostaining in adenoid cystic carcinomas of the salivary glands. Oral Oncology, (March 2007), Vol.43, No.3, pp.252-256, ISSN: 1368-8375.

Andrews GK. (2000). Regulation of metallothionein gene expression by oxidative stress and metal ions. Biochemical Pharmacology, (January 2000), Vol.59, No.1, pp.95-104, ISSN 0006-2952.

Barnes L, Eveson JW, Reichert PA \& Sidransky D. (2005). Pathology and Genetics of Head and Neck Tumours. IARC Press Lyon, ISBN 9283224 175, France.

Bay BH, Jin R \& Jaysurya A. (2001). Analysis of Metallothionein Expression in Human Cancers. Acta Histochemica et Cytochemica, (September 2001), Vol.34, No.3, pp.171176, ISSN 0044-5991.

Brunet A, Bonni A, Zigmond MJ, Lin MZ, Juo P, Hu LS, Anderson MJ, Arden KC, Blenis J \& Greenberg ME. (1999). Akt promotes cell survival by phosphorylating and inhibiting a Forkhead transcription factor. Cell, (March 1999), Vol.96, No.6, pp.857868, ISSN 0092-8674.

Cai L, Satoh M, Tohyama C \& Cherian MG. (1999). Metallothionein in radiation exposure: its induction and protective role. Toxicology, (February 1999), Vol. 132, No. 2-3, pp. 8598, ISSN 0300-483X.

Cardoso SV, Barbosa HM, Candellori IM, Loyola AM \& Aguiar MC. (2002). Prognostic impact of metallothionein on oral squamous cell carcinoma. Virchows Archives, (April 2002), Vol.441, No.2, pp.174-178, ISSN:0174-7398.

Cardoso SV, Silveira-Júnior JB, De Carvalho Machado V, De-Paula AM, Loyola AM \& De Aguiar MC. (2009). Expression of metallothionein and p53 antigens are correlated in oral squamous cell carcinoma. Anticancer Research, (April 2009), Vol.29, No.4, pp.1189-1193, ISSN 0250-7005.

Carnero A. (2010). The PKB/AKT pathway in cancer. Current Pharmaceutical Design, (January 2010), Vol.16, No.1, pp.34-44, ISSN 1381-6128. 
Chen CL, Chi CW \& Liu TY. (2002). Hydroxyl radical formation and oxidative DNA damage induced by areca quid in vivo. Journal of Toxicology and Environmental Health Part A, (February 2002), Vol.65, No.3-4, pp.327-336, ISSN 1528-7394.

Cherian MG \& Apostolova MD. (2000). Nuclear localization of metallothionein during cell proliferation and differentiation. Cellular and Molecular Biology (Noisy-le-grand), (March 2000), Vol.46, No.2, pp.347-356, ISSN 0145-5680.

Cherian MG \& Kang YJ. (2006). Metallothionein and liver cell regeneration. Experimental and Biological Medicine (Maywood, N.J.), (February 2006), Vol.231, No.2, pp.138-144, ISSN 1535-3699.

Cherian MG, Jayasurya A \& Bay BH. (2003). Metallothioneins in human tumors and potential roles in carcinogenesis. Mutation Research, (December 2003), Vol.533, No.1-2, pp.201-209, ISSN 0027-5107.

Chun JH, Kim HK, Kim E, Kim IH, Kim JH, Chang HJ, Choi IJ, Lim HS, Kim IJ, Kang HC, Park JH, Bae JM \& Park JG. (2004). Increased expression of metallothionein is associated with irinotecan resistance in gastric cancer. Cancer Research, (July 2004), Vol.64, No.14, pp.4703-4706, ISSN 0008-5472.

Coyle P, Philcox JC, Carey LC \& Rofe AM. (2002). Metallothionein: the multipurpose protein. Cellular and Molecular Life Sciences: CMLS, (April 2002), Vol.59, No.4, pp.627-647, ISSN 1420-682X.

da Cruz Perez DE, de Abreu Alves F, Nobuko Nishimoto I, de Almeida OP \& Kowalski LP. (2006). Prognostic factors in head and neck adenoid cystic carcinoma. Oral Oncology, (February 2006), Vol.42, No.2, pp.139-146, ISSN 1368-8375.

Davis SR \& Cousins RJ. (2000). Metallothionein expression in animals: a physiological perspective on function. The Journal of Nutrition, (May 2000), Vol.130, No.5, pp.10851088, ISSN 0022-3166.

Décline F \& Rousselle P. (2001). Keratinocyte migration requires alpha2beta1 integrinmediated interaction with the laminin 5 gamma2 chain. J Cell Sci, (February 2001), Vol.114, No.4, pp.811-823, ISSN 0021-9533.

Décline F, Okamoto O, Mallein-Gerin F, Helbert B, Bernaud J, Rigal D \& Rousselle P. (2003). Keratinocyte motility induced by TGF-beta1 is accompanied by dramatic changes in cellular interactions with laminin 5. Cell Motility and the Cytoskeleton, (January 2003), Vol. 54, No.1, pp.64-80, ISSN 0886-1544.

Diehl JA, Cheng M, Roussel MF \& Sherr CJ. (1998). Glycogen synthase kinase-3beta regulates cyclin D1 proteolysis and subcellular localization. Genes and Development, (November 1998), Vol.12, No.22, pp.3499-3511, ISSN 0890-9369.

Doerr TD, Prasad AS, Marks SC, Beck FW, Shamsa FH, Penny HS \& Mathog RH. (1997). Zinc deficiency in head and neck cancer patients. Journal of the American College of Nutrition, (October 1997), Vol.16, No.5, pp.418-422, ISSN 0731-5724.

Dziegiel P, Forgacz J, Suder E, Surowiak P, Kornafel J \& Zabel M. (2003). Prognostic significance of metallothionein expression in correlation with Ki-67 expression in adenocarcinomas of large intestine. Histology Histopathology, (April 2003), Vol. 18, No.2, pp.401-407, ISSN 0213-3911.

Dziegiel P, Salwa-Zurawska W, Zurawski J, Wojnar A \& Zabel M. (2005). Prognostic significance of augmented metallothionein (MT) expression correlated with Ki-67 antigen expression in selected soft tissue sarcomas. Histology Histopathology, (January 2005), Vol.20, No.1, pp. 83-89, ISSN 0213-3911. 
Dziegiel P. (2004). Expression of metallothioneins in tumor cells. Polish Journal of Pathology, (2004), Vol.55, No.1, pp.3-12, ISSN 1233-9687.

Fan LZ \& Cherian MG. (2002). Potential role of p53 on metallothionein induction in human epithelial breast cancer cells. British Journal of Cancer, (October 2002), Vol.87, No.9, pp.1019-1026, ISSN 0007-0920.

Fayard E, Xue G, Parcellier A, Bozulic L \& Hemmings BA. (2010). Protein kinase B (PKB/Akt), a key mediator of the PI3K signaling pathway. Current Topics in Microbiology and Immunology, (2010), Vol. 346, pp.31-56, ISSN 0070-217X.

Florianczyk B. (1998). Metallothioneins in rats exposed to cadmium. Roczniki Akademii Medycznej w Bialymstoku (1995), (1998); Vol.43, pp.309-313, ISSN 0067-6489.

Florianczyk B. (2003). Copper and metallothioneins in cancer cells. Annales Universitatis Mariae Curie Sklodowska. Sectio D: Medicina, (2003), Vol.58, No.2, pp.390-393, ISSN 0066-2240.

Fong LY, Jiang Y \& Farber JL. (2006). Zinc deficiency potentiates induction and progression of lingual and esophageal tumors in p53-deficient mice. Carcinogenesis, (July 2006), Vol.27, No. 7, pp.1489-1496, ISSN 0143-3334.

Fong LY, Zhang L, Jiang Y \& Farber JL. (2005). Dietary zinc modulation of COX-2 expression and lingual and esophageal carcinogenesis in rats. Journal of National Cancer Institute, (January 2005), Vol.97, No.1, pp.40-50, ISSN 0027-8874.

Freudlsperger C, Burnett JR, Friedman JA, Kannabiran VR, Chen Z \& Van Waes C. (2011). EGFR-PI3K-AKT-mTOR signaling in head and neck squamous cell carcinomas: attractive targets for molecular-oriented therapy. Expert Opinion on Therapeutic Targets, (January 2011), Vol.15, No.1, pp.63-74, ISSN 1472-8222.

Gao Y, Han Z \& Liu X. (1997). Metallothionein expression and its significance in salivary gland tumors. Zhonghua Kou Qiang Yi Xue Za Zhi, (1997), Vol.32, No.5, pp.282284, ISSN 1002-0098.

Ghoshal K, Majumder S, Zhu Q, Hunzeker J, Datta J, Shah M, Sheridan JF \& Jacob ST. (2001). Influenza virus infection induces metallothionein gene expression in the mouse liver and lung by overlapping but distinct molecular mechanisms. Molecular and Cellular Biology, (December 2001), Vol.21, No.24, pp.8301-8317, ISSN 0270-7306.

Grabinski N, Bartkowiak K, Grupp K, Brandt B, Pantel K \& Jücker M. (2011). Distinct functional roles of Akt isoforms for proliferation, survival, migration and EGFmediated signalling in lung cancer derived disseminated tumor cells. Cellular Signaling, (July 2011), ISSN 0898-6568.

Gupta PC \& Warnakulasuriya S. (2002). Global epidemiology of areca nut usage. Addiction Biology, (January 2002), Vol.7, No.1, pp.77-83, ISSN 1355-6215.

Haq F, Mahoney M \& Koropatnick J. (2003). Signaling events for metallothionein induction. Mutation Research, (December 2003), Vol.533, No.1-2, pp.211-226, ISSN 0027-5107.

Harpole DH Jr, Moore MB, Herndon JE 2nd, Aloia T, D'Amico TA, Sporn T, Parr A, Linoila I \& Allegra C. (2001). The prognostic value of molecular marker analysis in patients treated with trimodality therapy for esophageal cancer. Clinical Cancer Research, (March 2001), Vol.7, No.3, pp.562-569, ISSN 1078-0432.

Hecht D, Jung D, Prabhu VV, Munson PJ, Hoffman MP \& Kleinman HK. (2002). Metallothionein promotes laminin-1-induced acinar differentiation in vitro and reduces tumor growth in vivo. Cancer Research, (September 2002), Vol.62, No.18, pp.5370-5374, ISSN 0008-5472. 
Hengstler JG, Pilch H, Schmidt M, Dahlenburg H, Sagemüller J, Schiffer I, Oesch F, Knapstein PG, Kaina B \& Tanner B. (2001). Metallothionein expression in ovarian cancer in relation to histopathological parameters and molecular markers of prognosis. International Journal of Cancer, (March 2001), Vol.95, No.2, pp.121-127; ISSN 0020-7136.

Hernández J, Carrasco J, Belloso E, Giralt M, Bluethmann H, Kee Lee D, Andrews GK \& Hidalgo J. (2000). Metallothionein induction by restraint stress: role of glucocorticoids and IL-6. Cytokine, (June 2000), Vol.12, No.6, pp.791-796, ISSN 10434666.

Hidalgo J, Aschner M, Zatta P \& Vasák M. (2001). Roles of the metallothionein family of proteins in the central nervous system. Brain Research Bulletin, (May 2001), Vol.55, No.2, pp.133-145, ISSN 0361-9230.

Hoffman MP, Nomizu M, Roque E, Lee S, Jung DW, Yamada Y \& Kleinman HK. (1998). Laminin-1 and laminin-2 G-domain synthetic peptides bind syndecan-1 and are involved in acinar formation of a human submandibular gland cell line. The Journal of Biological Chemistry, (October 1998), Vol. 273, No.44, pp.28633-28641. Erratum in: The Journal of Biological Chemistry, (April 1999), Vol.274, No.18, p.12950, ISSN 1819$155 X$.

Hunt JL. (2011). An update on molecular diagnostics of squamous and salivary gland tumors of the head and neck. Archives of Pathology and Laboratory Medicine, (May 2011), Vol.135, No.5, pp.602-609, ISSN 0003-9985.

Ioachim E, Assimakopoulos D, Peschos D, Zissi A, Skevas A \& Agnantis NJ. (1999). Immunohistochemical expression of metallothionein in benign premalignant and malignant epithelium of the larynx: correlation with p53 and proliferative cell nuclear antigen. Pathological Research and Practice, (1999), Vol.195, No.12, pp.809814, ISSN 0344-0338.

Iqbal M, Noor R, Mizuno R \& Okada S. (2003). Protective role of zinc-metallothionein (Zn$\mathrm{MT}$ ) in iron nitrilotriacetate (Fe-NTA)-induced renal oxidative damage. Redox Report: Communications in Free Radicals Research, (2003), Vol.8, No.3, pp.163-167, ISSN 1351-0002.

Jasani B \& Schmid KW. (1997). Significance of metallothionein overexpression in human tumours. Histopathology, (September 1997), Vol.31, pp.211-214, ISSN 1365-2559.

Jayasurya A, Bay BH, Yap WM \& Tan NG. (2000). Correlation of metallothionein expression with apoptosis in nasopharyngeal carcinoma. British Journal of Cancer, (March 2000), Vol.82, No.6, pp.1198-1203, ISSN 0007-0920.

Jayasurya A, Bay BH, Yap WM, Tan NG \& Tan BK. (2000). Proliferative potential in nasopharyngeal carcinoma: correlations with metallothionein expression and tissue zinc levels. Carcinogenesis, (October 2000) Vol.21, No.10, pp.1809-1812, ISSN 01433334.

Jin R, Bay BH, Chow VT \& Tan PH. (2001). Metallothionein 1F mRNA expression correlates with histological grade in breast carcinoma. Breast Cancer Research and Treatment, (April 2001), Vol.66, No.3, pp.265-272, ISSN 0167-6806.

Johann AC, da Silveira-Júnior JB, Souto GR, Horta MC, Aguiar MC \& Mesquita RA. (2008) Metallothionein immunoexpression in oral leukoplakia. Medicina Oral, Patologia Oral y Cirugia Bucal, (March 2008), Mar 1;Vol.13, No.3, pp.156-160, ISSN 1698-4447. 
Kainulainen T, Autio-Harmainen H, Oikarinen A, Salo S, Tryggvason K \& Salo T. (1997). Altered distribution and synthesis of laminin-5 (kalinin) in oral lichen planus, epithelial dysplasias and squamous cell carcinomas. British Journal of Dermatology, (March 1997), Vol.136, No.3, pp.331-336, ISSN 0007-0963.

Kleier C, Werkmeister R \& Joos U. (1998). Zinc and vitamin A deficiency in diseases of the mouth mucosa. Mund-, Kiefer- und Gesichtschirurgie: MKG, (November 1998), Vol.2, No.6, pp.320-325, ISSN 1434-3940.

Ko YC, Huang YL, Lee CH, Chen MJ, Lin LM \& Tsai CC. (1995). Betel quid chewing, cigarette smoking and alcohol consumption related to oral cancer in Taiwan. Journal of Oral Pathology and Medicine, (November 1995) Vol.24, No.10, pp.450-453, ISSN 0904-2512.

Koizumi S, Suzuki K, Ogra Y, Yamada H \& Otsuka F. (1999). Transcriptional activity and regulatory protein binding of metal-responsive elements of the human metallothionein-IIA gene. European Journal of Biochemistry, (February 1999), Vol. 259, No.3, pp.635-642, ISSN 0014-2956.

Kwan HW. (1976). A statistical study on oral carcinomas in Taiwan with emphasis on the relationship with betel nut chewing: a preliminary report. Taiwan Yi Xue Hui Za Zhi, (September 1976), Vol.75, No.9, pp,497-505, ISSN 0371-7682.

Langmade SJ, Ravindra R, Daniels PJ \& Andrews GK. (2000). The transcription factor MTF-1 mediates metal regulation of the mouse ZnT1 gene. Journal of Biological Chemistry, (November 2000), Vol.275, No.44, pp.34803-34809, ISSN 0021-9258.

Lee SS, Yang SF, Ho YC, Tsai CH \& Chang YC. (2008). The upregulation of metallothionein1 expression in areca quid chewing-associated oral squamous cell carcinomas. Oral Oncology, (February 2008), Vol.44, No.2, pp.180-186, ISSN 1368-8375.

Levadoux-Martin M, Hesketh JE, Beattie JH, Wallace HM. Influence of metallothionein-1 localization on its function. The Biochemical Journal, (April 2001), Vol.355, No.2, pp.473-479; ISSN 0264-6021.

Lichtlen P, Wang Y, Belser T, Georgiev O, Certa U, Sack R \& Schaffner W. (2001). Target gene search for the metal-responsive transcription factor MTF-1. Nucleic Acids Research, (April 2001), Vol.29, No.7, pp.1514-1523, ISSN 0305-1048.

Lin WJ, Jiang RS, Wu SH, Chen FJ \& Liu SA. (2011). Smoking, alcohol, and betel quid and oral cancer: a prospective cohort study. Journal of Oncology, (2011), ISSN 1687-8450.

Liu CG, Zhang L, Jiang Y, Chatterjee D, Croce CM, Huebner K \& Fong LY. (2005). Modulation of gene expression in precancerous rat esophagus by dietary zinc deficit and replenishment. Cancer Research, (September 2005), Vol.65, No.17, pp.7790-7799, ISSN 0008-5472.

Lyons AJ \& Jones J. (2007). Cell adhesion molecules, the extracellular matrix and oral squamous carcinoma. International Journal of Oral and Maxillofacial Surgery, (August 2007), Vol.36, No.8, pp.671-679, ISSN 0901-5027.

Margoshes M \& Vallee B. (1957). A cadmium protein form equine kidney cortex. Journal of American Chemistry Society, (September 1957), Vol.79, No.17, pp.4813-4814, ISSN 1520-5126.

Méplan C, Richard MJ \& Hainaut P. (2000). Metalloregulation of the tumor suppressor protein p53: zinc mediates the renaturation of p53 after exposure to metal chelators in vitro and in intact cells. Oncogene, (November 2000), Vol.19, No.46, pp. 52275236, ISSN 0950-9232. 
Merchant A, Husain SS, Hosain M, Fikree FF, Pitiphat W, Siddiqui AR, Hayder SJ, Haider SM, Ikram M, Chuang SK \& Saeed SA. (2000). Paan without tobacco: an independent risk factor for oral cancer. International Journal of Cancer, (April 2000), Vol.86, No.1, pp.128-131, ISSN 0020-7136.

Mididoddi S, McGuirt JP, Sens MA, Todd JH \& Sens DA. (1996). Isoform-specific expression of metallothionein mRNA in the developing and adult human kidney. Toxicolgy Letters, (April 1996), Vol.85, No.1, pp.17-27; ISSN 0378-4274, ISSN online 1879-3169.

Mitropoulos D, Kyroudi-Voulgari A, Theocharis S, Serafetinides E, Moraitis E, Zervas A \& Kittas C. (2005). Prognostic significance of metallothionein expression in renal cell carcinoma. World Journal of Surgical Oncology, (January 2005), Vol.3, No.1, pp.5, ISSN 1477-7819.

Murata M, Gong P, Suzuki K \& Koizumi S. (1999). Differential metal response and regulation of human heavy metal-inducible genes. Journal of Cellullar Physiology, (July 1999), Vol.180, No.1, pp.105-113, ISSN 1097-4652.

Nair UJ, Obe G, Friesen M, Goldberg MT \& Bartsch H. (1992). Role of lime in the generation of reactive oxygen species from betel-quid ingredients. Environmental Health Perspectives, (November 1992), Vol.98, pp.203-205, ISSN 0091-6765.

Nakano M, Sogawa CA, Sogawa N, Mishima K, Yamachika E, Mizukawa N, Fukunaga J, Kawamoto T, Sawaki K, Sugahara T \& Furuta H. (2003). Expression pattern of cisplatin-induced metallothionein isoforms in squamous cell carcinoma. Anticancer Research, (January-February 2003), Vol.23, No.1A, pp.299-303, ISSN 0250-7005.

Nascimento AG, Amaral AL, Prado LA, Kligerman J \& Silveira TR. (1986). Adenoid cystic carcinoma of salivary glands. A study of 61 cases with clinicopathologic correlation. Cancer, (January 1986), Vol.57, No.2, pp.312-329, ISSN 0008-543X.

Nguyen T, Sherratt PJ \& Pickett CB. (2003). Regulatory mechanisms controlling gene expression mediated by the antioxidant response element. Annual Review of Pharmacology and Toxicology (January 2002), Vol.43, pp.233-260, ISSN 0362-1642.

Ogawa Y. (2003). Immunocytochemistry of myoepithelial cells in the salivary glands. Progress in Histochemistry and Cytochemistry, (2003) Vol.38, No.4, pp.343-426, ISSN 0079-6336.

Ogra Y, Suzuki K, Gong P, Otsuka F \& Koizumi S. (2001). Negative regulatory role of Sp1 in metal responsive element-mediated transcriptional activation. The Journal of Biological Chemistry, (May 2001), Vol.276, No.19, pp.16534-16539, ISSN 0021-9258.

Ono Y, Nakanishi Y, Ino Y, Niki T, Yamada T, Yoshimura K, Saikawa M, Nakajima T \& Hirohashi S. (1999). Clinocopathologic significance of laminin-5 gamma2 chain expression in squamous cell carcinoma of the tongue: immunohistochemical analysis of 67 lesions. Cancer, (June 1999), Vol.85 No.11, pp.2315-2321, ISSN 0008543X.

Ostrakhovitch EA, Olsson PE, Jiang S \& Cherian MG. (2006). Interaction of metallothionein with tumor suppressor p53 protein. FEBS Letters, (February 2006), Vol.580, No. 5, pp.1235-1258, ISSN 0014-5793.

Otsuka F, Okugaito I, Ohsawa M, Iwamatsu A, Suzuki K \& Koizumi S. (2000). Novel responses of ZRF, a variant of human MTF-1, to in vivo treatment with heavy metals. Biochimica et Biophysica Acta, (July 2000), Vol.1492, No.2-3, pp.330-340, ISSN 0167-4781. 
Palmiter RD, Findley SD, Whitmore TE \& Durnam DM. (1992). MT-III, a brain-specific member of the metallothionein gene family. Proceedings of National Academy of Sciences of the United States of America, (July 1992), Vol.89, No.14, pp.6333-6337, ISSN 0027-8424.

Palmiter RD. (1998). The elusive function of metallothioneins. Proceedings of National Academy of Sciences of the United States of America, (July 1998), Vol.95, No.15, pp.8428-8430, ISSN 0027-8424.

Pastuszewski W, Dziegiel P, Krecicki T, Podhorska-Okolow M, Ciesielska U, Gorzynska E \& Zabel M. (2007). Prognostic significance of metallothionein, p53 protein and Ki-67 antigen expression in laryngeal cancer. Anticancer Research, (January-February 2007), Vol.27, No.1A, pp.335-342, ISSN 0250-7005.

Patarroyo M, Tryggvason K \& Virtanen I. (2002). Laminin isoforms in tumor invasion, angiogenesis and metastasis. Seminars in Cancer Biology, (June 2002), Vol.12, No.3, pp.197-207, ISSN 1044-579X.

Pontes HA, de Aquino Xavier FC, da Silva TS, Fonseca FP, Paiva HB, Pontes FS \& dos Santos Pinto D Jr. (2009). Metallothionein and p-Akt proteins in oral dysplasia and in oral squamous cell carcinoma: an immunohistochemical study. Journal of Oral Pathology and Medicine, (September 2009), Vol.38, No.8, pp. 644-650, ISSN 0904-2512.

Prasad ML, Barbacioru CC, Rawal YB, Husein O \& Wen P. (2008). Hierarchical cluster analysis of myoepithelial/basal cell markers in adenoid cystic carcinoma and polymorphous low-grade adenocarcinoma. Modern Pathology, (February 2008), Vol.21, No.2, pp.105-114, ISSN 0893-3952.

Quaife CJ, Findley SD, Erickson JC, Froelick GJ, Kelly EJ, Zambrowicz BP \& Palmiter RD. (1994). Induction of a new metallothionein isoform (MT-IV) occurs during differentiation of stratified squamous epithelia. Biochemistry, (June 1994), Vol.33, No.23, pp.7250-7259, ISSN 0006-2960.

Rainwater R, Parks D, Anderson ME, Tegtmeyer P \& Mann K. (1995). Role of cysteine residues in regulation of p53 function. Molecular Cell Biology, (July 1995), Vol.15, No.7, pp.3892-3903, ISSN 0270-7306.

Rainwater R, Parks D, Anderson ME, Tegtmeyer P \& Mann K. (1995). Role of cysteine residues in regulation of p53 function. Molecular and Cellular Biology, (July 1995), Vol.15, No.7, pp.3892-3903, ISSN 0270-7306.

Reinecke F, Levanets O, Olivier Y, Louw R, Semete B, Grobler A, Hidalgo J, Smeitink J, Olckers A \& Van der Westhuizen FH. (2006). Metallothionein isoform 2A expression is inducible and protects against ROS-mediated cell death in rotenonetreated HeLa cells. Biochemistry Journal, (April 2006), Vol.395, No.2, pp.405-415, ISSN 0264-6021.

Remmele W \& Stegner HE. (1987). Recommendation for uniform definition of an immunoreactive score (IRS) for immunohistochemical estrogen receptor detection (ER-ICA) in breast cancer tissue. Pathologe, (May 1987), Vol.8, No.3, pp.138-140, ISSN 0172-8113.

Samson SL \& Gedamu L. (1998). Molecular analyses of metallothionein gene regulation. Progress in Nucleic Acid Research and Molecular Biology, (1998), Vol.59, pp.257-288; ISSN 0079-6603.

Saydam N, Adams TK, Steiner F, Schaffner W \& Freedman JH. (2002). Regulation of metallothionein transcription by the metal-responsive transcription factor MTF-1: 
identification of signal transduction cascades that control metal-inducible transcription. Journal of Biological Chemistry, (June 2002), Vol.277, No.23, pp. 2043820445, ISSN 0021-9258.

Shimoda R, Achanzar WE, Qu W, Nagamine T, Takagi H, Mori M \& Waalkes MP. (2003). Metallothionein is a potential negative regulator of apoptosis. Toxicological Sciences, (June 2003), Vol.73, No.2, pp.294-300, ISSN 1096-6080.

Shiu MN \& Chen TH. (2004). Impact of betel quid, tobacco and alcohol on three-stage disease natural history of oral leukoplakia and cancer: implication for prevention of oral cancer. European Journal of Cancer Prevention, (February 2004), Vol.13, No.1, pp.39-45, ISSN 0959-8278.

Siegel R, Ward E, Brawley O \& Jemal A. (2011). Cancer statistics, 2011: The impact of eliminating socioeconomic and racial disparities on premature cancer deaths. CA: $a$ Cancer Journal for Clinicians, Vol.61, No.4, (July-August 2011), pp. 212-236, ISSN 0007-9235.

Stoltzfus P, Högmo A, Lindholm J, Aspenblad U, Auer G \& Munck-Wikland E. (2004). The gamma2 chain of laminin-5 as an indicator of increased risk for recurrence in T1 stage tongue cancer. Anticancer Research, (September-October 2004), Vol.24, No.5B, pp.3109-3114, ISSN 0250-7005.

Sunardhi-Widyaputra S, van den Oord JJ, Van Houdt K, De Ley M \& Van Damme B. (1995). Identification of Metallothionein- and parathyroid hormone-related peptide (PTHrP)-positive cells in salivary gland tumours. Pathology Research and Practice, (November 1995), Vol.191, No.11, pp.1092-1098, ISSN 0344-0338.

Sundelin K, Jadner M, Norberg-Spaak L, Davidsson A \& Hellquist HB. (1997). Metallothionein and Fas (CD95) are expressed in squamous cell carcinoma of the tongue. European Journal of Cancer, (October 1997), Vol.33, No.11, pp.1860-1864, ISSN 0959-8049.

Surowiak P, Materna V, Kaplenko I, Spaczyński M, Dietel M, Lage H \& Zabel M. (2005) Augmented expression of metallothionein and glutathione S-transferase pi as unfavourable prognostic factors in cisplatin-treated ovarian cancer patients. Virchows Archives, (September 2005), Vol.447, No.3, pp.626-633, ISSN 0945-6317.

Surowiak P, Materna V, Maciejczyk A, Pudełko M, Markwitz E, Spaczyński M, Dietel M, Zabel M \& Lage H. (2007). Nuclear metallothionein expression correlates with cisplatin resistance of ovarian cancer cells and poor clinical outcome. Virchows Archives, (March 2007) Vol.450, No.3, pp.279-285, ISSN 0945-6317.

Szajerka A, Dziegiel P, Szajerka T, Zabel M, Winowski J \& Grzebieniak Z. (2008). Immunohistochemical evaluation of metallothionein, Mcm-2 and Ki-67 antigen expression in tumors of the adrenal cortex. Anticancer Research, (September-October 2008), Vol.28, No.5B, pp.2959-2265, ISSN 0250-7005.

Szelachowska J, Dziegiel P, Jelen-Krzeszewska J, Jelen M, Tarkowski R, Spytkowska B, Matkowski R \& Kornafel J. (2009). Correlation of metallothionein expression with clinical progression of cancer in the oral cavity. Anticancer Research, (February 2009), Vol.29, No.2, pp.589-595, ISSN 0250-7005.

Szelachowska J, Dziegiel P, Jelen-Krzeszewska J, Jelen M, Tarkowski R, Wlodarska I, Spytkowska B, Gisterek I, Matkowski R \& Kornafel J. (2008). Prognostic significance of nuclear and cytoplasmic expression of metallothioneins as related to 
proliferative activity in squamous cell carcinomas of oral cavity. Histology Histopathology, (July 2008), Vol.23, No.7, pp.843-551, ISSN 0213-3911.

Theocharis SE, Margeli AP, Klijanienko JT \& Kouraklis GP. (2004). Metallothionein expression in human neoplasia. Histopathology, (August 2004), Vol.45, No.2, pp.103118, ISSN 0309-0167.

Trivedy C, Baldwin D, Warnakulasuriya S, Johnson N \& Peters T. (1997). Copper content in Areca catechu (betel nut) products and oral submucous fibrosis. Lancet. (May 1997), Vol.349, No.9063, p.1447, ISSN 0140-6736.

Vasák M \& Hasler DW. (2000). Metallothioneins: new functional and structural insights. Current Opinion in Chemical Biology, (April 2000), Vol.4, No.2, pp.177-183, ISSN 1367-5931.

Vasák M. (2005). Advances in metallothionein structure and functions. Journal of Trace Elements in Medicine and Biology, (2005), Vol.19, No.1, pp.13-17, ISSN 0946-672X.

Vázquez-Ramírez FJ, González-Cámpora JJ, Hevia-Alvarez E, Fernández-Santos JM, RíosMartín JJ, Otal-Salaverri C \& González-Cámpora R. (2000). P-glycoprotein, metallothionein and NM23 protein expressions in breast carcinoma. Pathology, Research and Practice, (2000), Vol.196, No.8, pp. 553-559, ISSN 0344-0338.

West KA, Brognard J, Clark AS, Linnoila IR, Yang X, Swain SM, Harris C, Belinsky S \& Dennis PA. (2003). Rapid Akt activation by nicotine and a tobacco carcinogen modulates the phenotype of normal human airway epithelial cells. Journal of Clin Investigation, (January 2003), Vol.111, No.1, pp.81-90, ISSN 0021-9738.

West KA, Linnoila IR, Brognard J, Belinsky S, Harris C \& Dennis PA. (2004). Tobacco carcinogen-induced cellular transformation increases Akt activation in vitro and in vivo. Chest, (May 2004) Vol.125, No.5, pp.101-102, ISSN 0012-3692.

Woo ES, Kondo Y, Watkins SC, Hoyt DG \& Lazo JS. (1996). Nucleophilic distribution of metallothionein in human tumor cells. Experimental Cell Research, (May 1996), Vol.224., No.2, pp.365-371, ISSN 0014-4827.

Yamamoto M, Tsujinaka T, Shiozaki H, Doki Y, Tamura S, Inoue M, Hirao M \& Monden M. (1999). Metallothionein expression correlates with the pathological response of patients with esophageal cancer undergoing preoperative chemoradiation therapy. Oncology, (1999), Vol.56, No.4, pp.332-337, ISSN 0030-2414.

Zalups RK, Fraser J \& Koropatnick J. (1995). Enhanced transcription of metallothionein genes in rat kidney: effect of uninephrectomy and compensatory renal growth. American Journal of Physiology, (April 1995), Vol.268, No.4 Pt 2, pp.F643-F650, ISSN 1931-857X.

Zangger K, Shen G, Oz G, Otvos JD \& Armitage IM. (2001). Oxidative dimerization in metallothionein is a result of intermolecular disulphide bonds between cysteines in the alpha-domain. Biochemical Journal, (October 2001), Vol.359, No.2, pp.353-360, ISSN 0264-6021. 


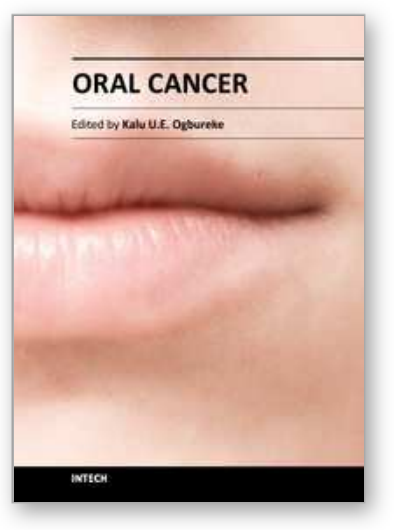

\author{
Oral Cancer \\ Edited by Dr. Kalu U. E. Ogbureke
}

ISBN 978-953-51-0228-1

Hard cover, 388 pages

Publisher InTech

Published online 14, March, 2012

Published in print edition March, 2012

Oral cancer is a significant public health challenge globally. Although the oral cavity is easily accessible, early diagnosis remains slow compared to the enhanced detection of cancers of the breast, colon, prostate, and melanoma. As a result, the mortality rate from oral cancer for the past four decades has remained high at over $50 \%$ in spite of advances in treatment modalities. This contrasts with considerable decrease in mortality rates for cancers of the breast, colon, prostate, and melanoma during the same period. This book attempts to provide a reference-friendly update on the etiologic/risk factors, current clinical diagnostic tools, management philosophies, molecular biomarkers, and progression indicators of oral cancer.

\title{
How to reference
}

In order to correctly reference this scholarly work, feel free to copy and paste the following:

Dziegiel Piotr, Pula Bartosz and Podhorska-Okolow Marzena (2012). Expression of Metallothionein in Oral Cancer, Oral Cancer, Dr. Kalu U. E. Ogbureke (Ed.), ISBN: 978-953-51-0228-1, InTech, Available from: http://www.intechopen.com/books/oral-cancer/expression-of-metallothionein-in-oral-cancer

\section{INTECH}

open science | open minds

\section{InTech Europe}

University Campus STeP Ri

Slavka Krautzeka 83/A

51000 Rijeka, Croatia

Phone: +385 (51) 770447

Fax: +385 (51) 686166

www.intechopen.com

\section{InTech China}

Unit 405, Office Block, Hotel Equatorial Shanghai

No.65, Yan An Road (West), Shanghai, 200040, China

中国上海市延安西路65号上海国际贵都大饭店办公楼 405 单元

Phone: +86-21-62489820

Fax: +86-21-62489821 
(C) 2012 The Author(s). Licensee IntechOpen. This is an open access article distributed under the terms of the Creative Commons Attribution 3.0 License, which permits unrestricted use, distribution, and reproduction in any medium, provided the original work is properly cited. 